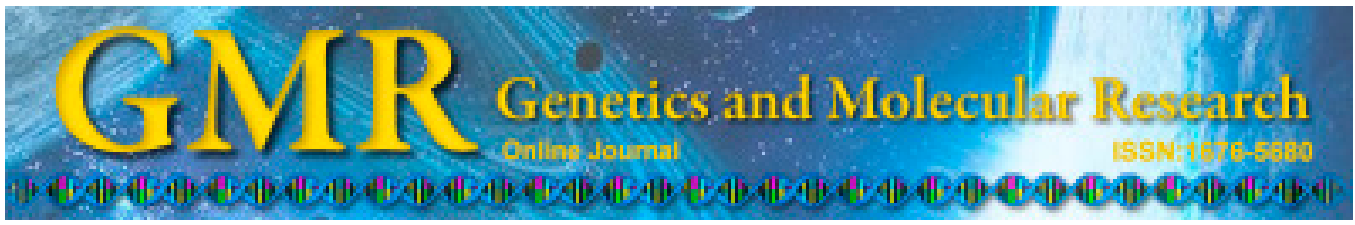

\title{
Leptin and leptin receptor gene polymorphisms are correlated with production performance in the Arctic fox
}

\author{
M. Zhang ${ }^{1}$ and X.J. Bai ${ }^{2}$ \\ ${ }^{1}$ College of Animal Husbandry and Veterinary Medicine, \\ Liaoning Medical College, Jinzhou, China \\ ${ }^{2}$ College of Animal Science and Technology, Northeast Agricultural University, \\ Harbin, China
}

Corresponding author: M. Zhang

E-mail: zhangmin5266@163.com

Genet. Mol. Res. 14 (2): 5560-5570 (2015)

Received July 21, 2014

Accepted November 18, 2014

Published May 25, 2015

DOI http://dx.doi.org/10.4238/2015.May.25.7

\begin{abstract}
The polymerase chain reaction-single-strand conformation polymorphism technique was employed to measure mononucleotide diversity in the coding region of the leptin and leptin receptor genes in the Arctic fox. The relationships between specific genetic mutations and reproductive performance in Arctic foxes were determined to improve breeding strategies. We found that a leptin gene polymorphism was significantly associated with body weight $(\mathrm{P}<0.01)$, abdominal circumference $(\mathrm{P}<0.01)$, and fur length $(\mathrm{P}<0.01)$. Furthermore, a polymorphism in the leptin receptor gene was associated with carcass weight and guard hair length $(\mathrm{P}<0.01)$. Leptin and leptin receptor gene combinatorial genotypes were significantly associated with abdominal circumference, fur length $(\mathrm{P}<0.01)$, and body weight $(\mathrm{P}<0.05)$. The leptin gene is thus a key gene affecting body weight, abdominal circumference, and fur length in Arctic foxes, whereas variations in the leptin receptor mainly affect carcass weight and guard hair. The marker loci identified in this study can be used to assist in the selection of Arctic
\end{abstract}


foxes for breeding to raise the production performance of this species.

Key words: Arctic fox; Leptin gene; Leptin receptor gene; Polymorphism; Production performance

\section{INTRODUCTION}

The Arctic fox, also known as the Blue fox (Alopex lagopus), belongs to the canine family and is native to high-latitude areas of northern Asia, Europe, and North America. Arctic fox fur is very economically valuable in the international market. The development of modern biotechnology thus has immense potential for the breeding industry of this and other species used for fur production and may greatly accelerate the improvement of fur animal science.

Leptin is a polypeptide hormone produced mainly by white adipose tissue. Leptin is a cytokine that acts on satiety centers in the hypothalamus and, by binding to its specific receptor OB-Rb, plays a crucial role in controlling appetite, body weight, fat content, and total energy balance (Liu et al., 2011).

In 1994, Zhang et al. (1994) cloned the mouse obese gene (OB). This gene, also known as the leptin gene, encodes the 167-amino acid leptin protein, which is located on chromosome 7q31.3. The porcine OB gene is located on chromosome 18, while the human OB gene is located on chromosome $7 \mathrm{q} 31.3$. The human gene is approximately $20-\mathrm{kb}$ long and is composed of 3 exons and 2 introns.

In rats, the cDNA sequence encoding the full-length leptin protein is $2.9 \mathrm{~kb}$ in length. The 5' untranslated region is 114-bp long and precedes an open reading frame of $501 \mathrm{bp}$. In pigs, the full-length leptin cDNA sequence is 3327 bp (Dai et al., 2000). Pig varieties with different lean meat percentages exhibit leptin sequences of varying lengths. For example, lean pigs express a $4.2-\mathrm{kb}$ cDNA variant, whereas fat-type pigs express a $3.3-\mathrm{kb}$ sequence. To date, OB genes have been cloned from many vertebrate species, including rat, mouse, human, pig, dog, and chicken. The coding region of the OB gene is highly conserved among species.

Leptin exerts its effects through the leptin receptor (LEPR), which plays a key role in the control of food intake and energy homeostasis (Ovilo et al., 2010). The LEPR gene is located on chromosome 4, and mutations in this gene are recessive. Tartaglia et al. (1995) first isolated and cloned the leptin receptor (LEPR, also known as OB-R) using expression cloning. They verified that the receptor belongs to the class I cytokine receptor family and is located on rat chromosome 4 within the db locus. The human leptin receptor gene is located at chromosome $1 \mathrm{p} 31$ and is composed of 20 exons and 19 introns. This gene is primarily expressed as a single transmembrane receptor in the hypothalamus.

Leptin- and leptin receptor-related disorders can lead to obesity, insulin resistance, and abnormal energy metabolism. The genes encoding leptin and the leptin receptor are potential quantitative trait loci affecting body fat content, food intake, and satiety.

In this study, we used Arctic foxes from the fox and raccoon dog farm of the Greater Khingan Tuqiang Forestry Bureau as experimental materials. We evaluated potential mutation sites in the OB and OB-R genes in individual Arctic foxes, analyzed correlations between these sites and growth traits using quantitative genetics and biostatistics, and calculated the rates of allele-specific contributions to character heredity. Our results will help to identify a favorable genotype related to production performance that may improve Arctic fox breeding programs. 


\section{MATERIAL AND METHODS}

\section{Animal and data sources}

Samples were collected from the Great Khingan Tuqiang Forestry Bureau, Heilongjiang, China. Body weight, body length, and abdominal circumference were measured in 297 Arctic foxes (91 females and 206 males). Data related to skin length and guard hair length in the hide were obtained from 421 foxes (209 females and 212 males). Therefore, data were collected for a total of 421 Arctic foxes (Table 1).

\begin{tabular}{|c|c|c|c|c|c|}
\hline $\begin{array}{l}\text { Arctic fox } \\
\text { test samples }\end{array}$ & $\begin{array}{c}\text { No. with } \\
\text { weight records }\end{array}$ & $\begin{array}{l}\text { No. with body } \\
\text { length records }\end{array}$ & $\begin{array}{l}\text { No. with abdominal } \\
\text { circumference records }\end{array}$ & $\begin{array}{l}\text { No. with animal hide } \\
\text { and skin length records }\end{array}$ & $\begin{array}{c}\text { No. with guard } \\
\text { hair length records }\end{array}$ \\
\hline Female & 91 & 91 & 91 & 209 & 209 \\
\hline Male & 206 & 206 & 206 & 212 & 212 \\
\hline Total & & 297 & & & \\
\hline
\end{tabular}

This experiment was carried out according to the Animal Ethics Procedures and Guidelines of the People's Republic of China. The study was approved by the Ethical Committee for Animal Experiments of the Institutional Animal Care and Use Committee in Liaoning Medical College. All efforts were made to minimize suffering. No other specific permissions were required for these activities. This study did not involve endangered or protected species.

\section{Polymerase chain reaction (PCR) amplification of the $\mathrm{OB}$ and $\mathrm{OB}-\mathrm{R}$ genes}

Primers were designed using publicly available dog OB and OB-R cDNA sequences (GenBank Accession No. AB020986.1 and AB190512.1) and are listed in Table 2. Each 25- $\mu \mathrm{L}$ PCR mixture consisted of $1.0 \mu \mathrm{L}$ genomic DNA, $2.5 \mu \mathrm{L}$ PCR buffer, $200 \mu \mathrm{M}$ dNTPs, $4 \mathrm{mM} \mathrm{MgCl}{ }_{2}$, $0.5 \mu \mathrm{M}$ primer, $1.25 \mathrm{U}$ Taq polymerase (TaKaRa, Shiga, Japan), and sterile double-distilled water.

\begin{tabular}{llrl}
\multicolumn{2}{c}{ Table 2. OB gene PCR-SSCP primer sequences, product size, and location. } & Product Size & Product position \\
\hline OB & Primer & 249 bp & Exon 3 \\
OB-R & $\begin{array}{l}\text { Forward 5' GGCTTTAGCGAATAGTCCC 3' } \\
\text { Reverse 5' AGCCCATAGCACCAATCA 3' }\end{array}$ & $159 \mathrm{bp}$ & Exon4 \\
\hline
\end{tabular}

\section{Cycle parameters for the OB gene}

Samples were subjected to the following thermal amplification profile: 5 min of initial denaturation at $94^{\circ} \mathrm{C}$, then 35 cycles of $40 \mathrm{sec}$ of denaturation at $94^{\circ} \mathrm{C}, 30 \mathrm{sec}$ of annealing at $45^{\circ} \mathrm{C}$ and $35 \mathrm{sec}$ of elongation at $72^{\circ} \mathrm{C}$, with a final elongation step for $10 \mathrm{~min}$ at $72^{\circ} \mathrm{C}$.

\section{Cycle parameters for the OB-R gene}

Samples were subjected to the following thermal amplification profile: 5 min of initial 
denaturation at $94^{\circ} \mathrm{C}$, then 35 cycles of $40 \mathrm{sec}$ of denaturation at $94^{\circ} \mathrm{C}, 30 \mathrm{sec}$ of annealing at $53.8^{\circ} \mathrm{C}$, and $35 \mathrm{sec}$ of elongation at $72^{\circ} \mathrm{C}$, with a final elongation step for $10 \mathrm{~min}$ at $72^{\circ} \mathrm{C}$.

\section{Single nucleotide polymorphism (SNP) detection in the OB and OB-R genes}

The separation of amplified fragments was performed on $12 \%$ denaturing acrylamide gels [acrylamide: bisacrylamide (19:1), 1X TAE] at $90 \mathrm{~V}$ for $2.5 \mathrm{~h}$. The gels were stained with $0.1 \%$ $\mathrm{AgNO}_{3}$ solution and digitally photographed. Correlations between the genotypes and population traits of Arctic foxes were analyzed using the SPSS 13.0 software (SPSS, Inc., Chicago, IL, USA).

\section{Statistical analysis}

Descriptive statistics, including tests of the normality of the distribution of traits, were calculated using univariate and means procedures using the SPSS software 13.0. The following model was used to estimate the genetic parameters of production performance:

$$
\mathrm{Y}=\mu+\mathrm{G}+\mathrm{L}+\mathrm{G} \times \mathrm{L}+\mathrm{e}
$$

where $Y=$ property determination value, $\mu=$ mean of the population, $G=$ genotype effect, $L$ $=$ strain effect, $G \times L=$ strain and genotype interaction effect, and $e=$ random residual error.

\section{RESULTS}

\section{Point mutation detection in the $\mathrm{OB}$ gene}

Agarose gel electrophoresis revealed that the OB gene product amplified by PCR was approximately $246 \mathrm{bp}$, as predicted (Figure 1). This product was suitable for PCR-singlestrand conformation polymorphism (SSCP) analysis. PCR products were separated by $12 \%$ polyacrylamide gel electrophoresis followed by silver staining. A total of 3 genotypes were detected, referred to as $\mathrm{AA}, \mathrm{BB}$, and $\mathrm{AB}$ (Figure 2). The polymorphic fragments amplified from the $\mathrm{AA}$ and $\mathrm{BB}$ samples were sequenced (Figure 3).

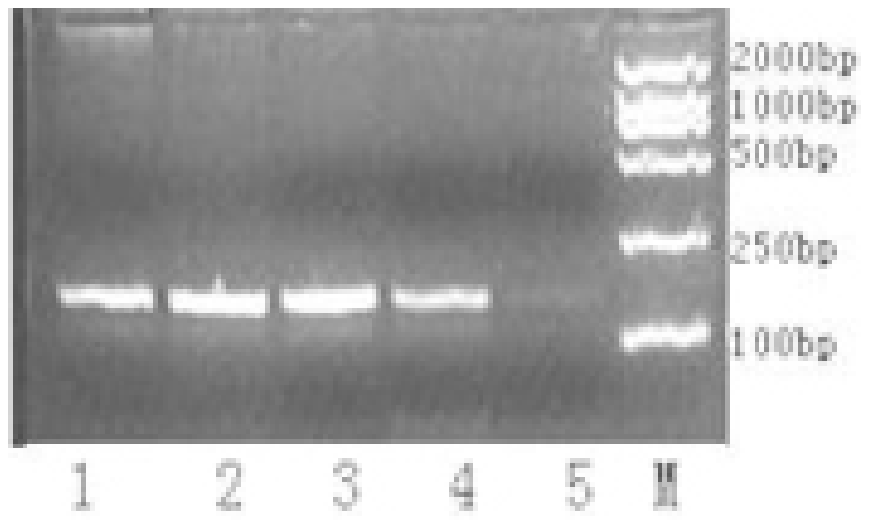

Figure 1. Electrophoresis results of PCR amplification on OB gene 3rd exon. Lane M is Marker DL2000. Lanes 1-4 PCR product; lane 5 is negative. 


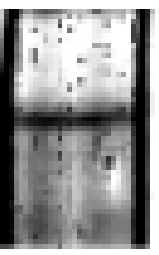

$\mathrm{BB}$

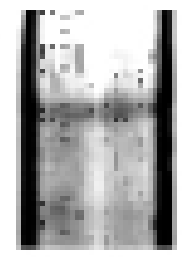

$\mathrm{BB}$

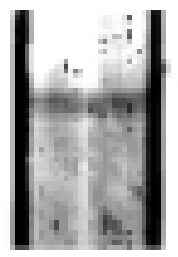

BB

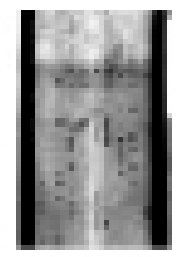

AA
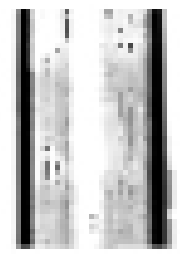

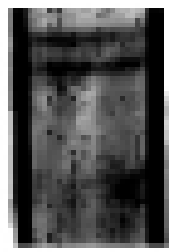

$A B$

$\mathrm{AB}$

Figure 2. Different genotypes determined by PCR-SSCP.

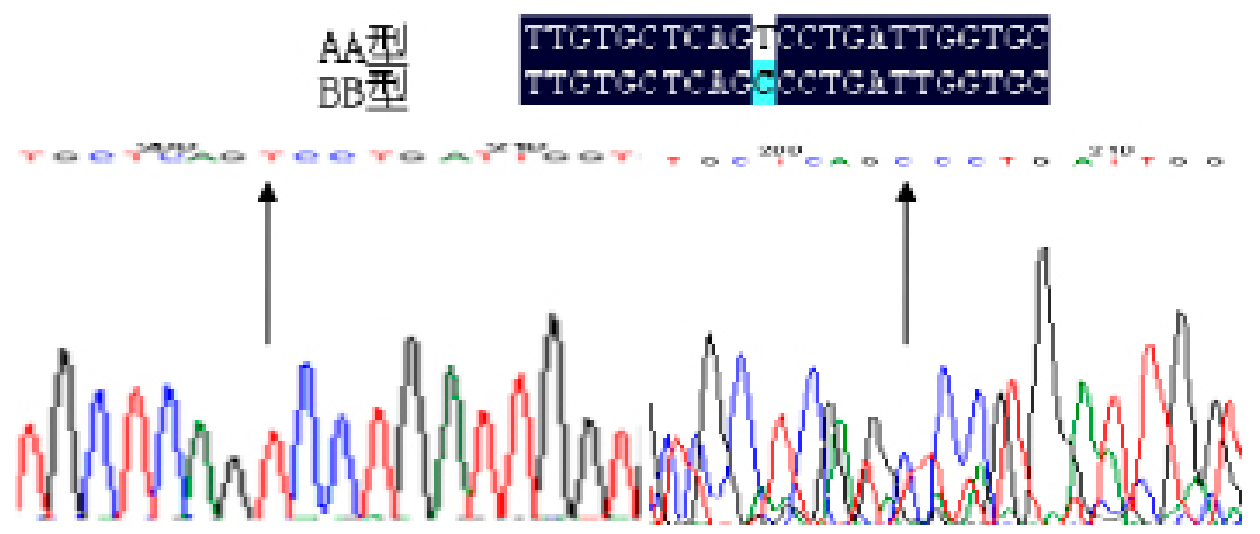

Figure 3. Sequencing results of $\mathrm{AA}$ and $\mathrm{BB}$ genotypes.

\section{Correlation between the $\mathrm{OB}$ gene polymorphism and production performance in Arctic fox}

In our sample, the gene frequencies of the A and $\mathrm{B} O \mathrm{OB}$ alleles were 0.536 and 0.464 , respectively, whereas the $\mathrm{AA}, \mathrm{BB}$, and $\mathrm{AB}$ genotype frequencies were $0.191,0.119$, and $0.69 \%$ (Table 3). A highly significant difference in body weight was observed among the 3 genotypes $(10.33 \pm 0.16,9.05 \pm 0.30$, and $8.93 \pm 0.34 \mathrm{~kg}$ for the $\mathrm{AB}, \mathrm{AA}$, and $\mathrm{BB}$ genotypes, respectively; $\mathrm{P}<0.01)$. Similarly, abdominal circumference significantly differed between the $\mathrm{AB}, \mathrm{AA}$, and $\mathrm{BB}$ genotypes $(61.47 \pm 0.49,58.38 \pm 1.2$, and $56.30 \pm 0.84 \mathrm{~cm}$; respectively $\mathrm{P}<0.01)$ (Table 4$)$.

Table 3. Allele gene frequency and genotype frequency of the OB gene polymorphic loci.

\begin{tabular}{cccccccc}
\hline Arctic foxes & Number of samples & \multicolumn{2}{c}{ Allele gene frequency } & & \multicolumn{3}{c}{ Genotype frequency } \\
\cline { 2 - 3 } \cline { 5 - 7 } & 546 & $\mathrm{~A}$ & $\mathrm{~B}$ & & AA & $\mathrm{BB}$ & $\mathrm{AB}$ \\
\hline & 0.536 & 0.464 & & $0.191(105)$ & $0.119(65)$ & $0.690(376)$ \\
\hline
\end{tabular}

Table 4. Effect of the OB gene polymorphism on body weight, body length, and abdominal circumference.

\begin{tabular}{lcrr}
\hline Genotype & Number & Body weight & Abdominal circumference \\
\hline AA & 39 & $9.05 \pm 0.30^{\mathrm{B}}$ & $58.38 \pm 1.2^{\mathrm{B}}$ \\
BB & 23 & $8.93 \pm 0.34^{\mathrm{B}}$ & $56.30 \pm 0.84^{\mathrm{B}}$ \\
AB & 154 & $10.33 \pm 0.16^{\mathrm{A}}$ & $61.47 \pm 0.49^{\mathrm{A}}$ \\
\hline
\end{tabular}

Values in same column capitals indicate $\mathrm{P}<0.01$. 
The fur lengths of the $\mathrm{AB}$ and $\mathrm{AA}$ genotypes were significantly different $(100.43 \pm$ 0.55 vs $95.606 \pm 1.7 \mathrm{~cm} ; \mathrm{P}<0.01)$ (Table 5).

Table 5. Effect of the OB gene polymorphism on fur length and guard hair length.

\begin{tabular}{lcr}
\hline Genotype & Number & \multicolumn{1}{c}{ Fur length } \\
\hline AA & 66 & $95.606 \pm 1.7^{\mathrm{B}}$ \\
BB & 42 & $98.14 \pm 1.2^{\mathrm{AB}}$ \\
AB & 222 & $100.43 \pm 0.55^{\mathrm{A}}$ \\
\hline
\end{tabular}

Values in same column capitals indicate $\mathrm{P}<0.01$.

\section{Detection of a point mutation in the OB-R gene}

Agarose gel electrophoresis revealed that the OB-R gene product amplified by PCR was approximately $159 \mathrm{bp}$ (Figure 4), and was suitable for PCR-SSCP analysis. PCR products were separated by $12 \%$ polyacrylamide gel electrophoresis followed by silver staining. A total of 3 genotypes were detected, including AA, BB, and $\mathrm{AB}$ (Figure 5). The polymorphic fragments amplified from the AA and BB samples were sequenced (Figure 6).

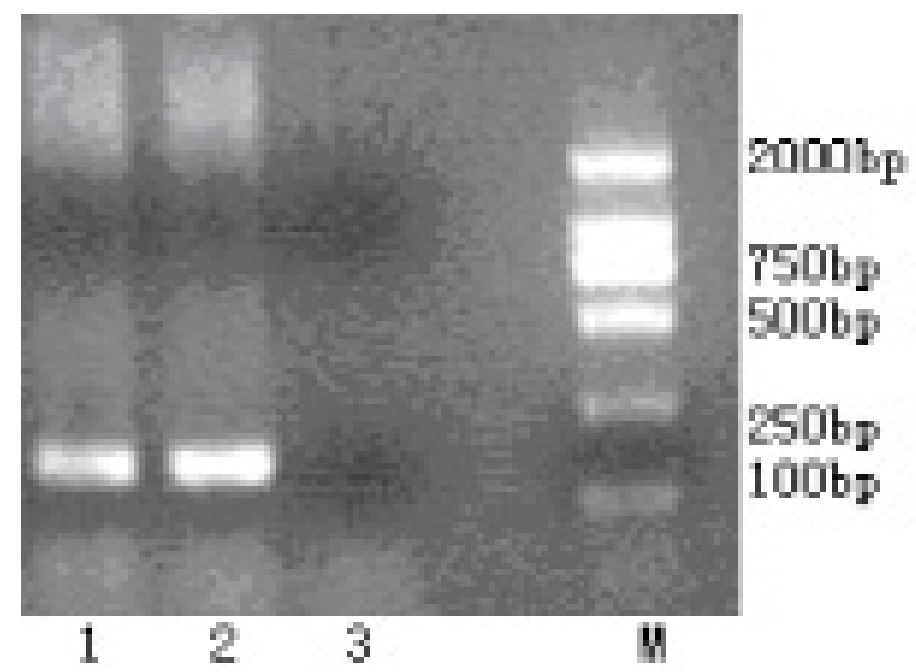

Figure 4. Results of PCR amplification on the OB-R gene 4th exon. Lane M is Marker DL2000. Lanes 1-2 PCR product; lane 3 is negative.

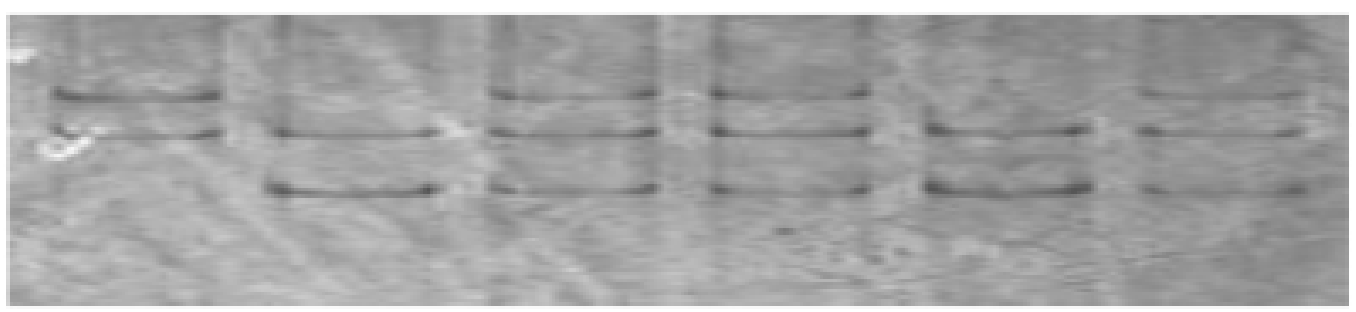

Figure 5. Results of different genotypes determined by PCR-SSCP. 


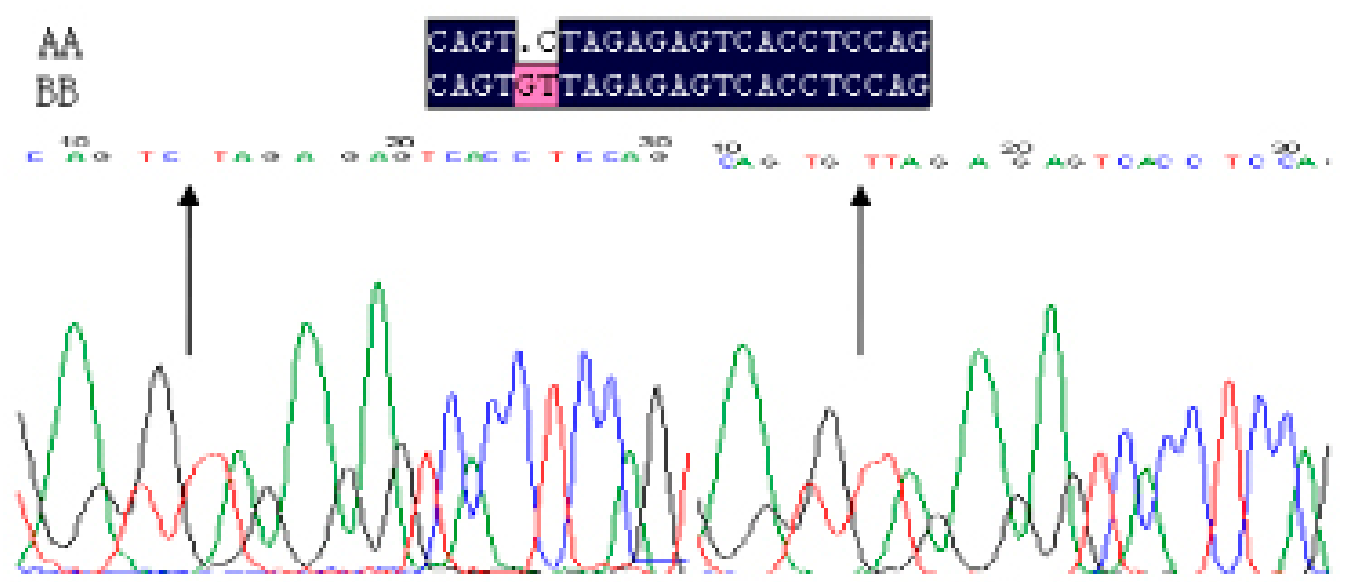

Figure 6. Sequencing result of AA and BB genotypes.

\section{Correlation between the $\mathrm{OB}-\mathrm{R}$ gene polymorphism and production performance in Arctic fox}

In our sample, the gene frequencies of the OB-R A and B alleles were 0.265 and 0.735 , respectively, whereas the $\mathrm{AA}, \mathrm{BB}$, and $\mathrm{AB}$ genotype frequencies were $0.039,0.509$, and $0.452 \%$ (Table 6 ). A highly significant difference in carcass weight was observed between the $\mathrm{AB}$ and $\mathrm{BB}$ genotypes $(7.79 \pm 0.73$ vs $6.146 \pm 0.26 \mathrm{~kg} ; \mathrm{P}<0.01)$ (Table 7). Similarly, a significant difference in guard hair length was observed between the BB and AA genotypes $(6.225 \pm 0.067$ vs $5.500 \pm 0.20 \mathrm{~cm} ; \mathrm{P}<0.01)$ (Table 8).

Table 6. Allele gene frequency and genotype frequency of OB-R gene polymorphic loci.

\begin{tabular}{|c|c|c|c|c|c|c|}
\hline \multirow[t]{2}{*}{ Arctic foxes } & \multirow[t]{2}{*}{ No. of samples } & \multicolumn{2}{|c|}{ Allele gene frequency } & \multicolumn{3}{|c|}{ Genotype frequency } \\
\hline & & $\mathrm{A}$ & $\mathrm{B}$ & AA & $\mathrm{BB}$ & $\mathrm{AB}$ \\
\hline & 515 & 0.265 & 0.735 & $0.039(20)$ & $0.509(262)$ & $0.452(233)$ \\
\hline
\end{tabular}

Table 7. Effect of OB-R gene polymorphism on carcass weight.

\begin{tabular}{lcr}
\hline Genotype & Number & Carcass weight P $<0.01$ \\
\hline BB & 11 & $6.146 \pm 0.26^{\mathrm{A}}$ \\
AB & 11 & $7.97 \pm 0.43^{\mathrm{B}}$ \\
\hline
\end{tabular}

Values in same column capitals indicate $\mathrm{P}<0.01$.

Table 8. Effect of OB-R gene polymorphism on fur length and guard hair length.

\begin{tabular}{lcc}
\hline Genotype & Number & Guard hair length $\mathrm{P}<0.01$ \\
\hline AA & 10 & $5.500 \pm 0.20^{\mathrm{B}}$ \\
BB & 180 & $6.225 \pm 0.067^{\mathrm{A}}$ \\
AB & 137 & $5.974 \pm 0.067^{\mathrm{AB}}$ \\
\hline
\end{tabular}

Values in same column capitals indicate $\mathrm{P}<0.01$. 


\section{Effect of $\mathrm{OB}$ and $\mathrm{OB}-\mathrm{R}$ gene polymorphisms on the production performance of Arctic fox}

A highly significant difference in guard hair length was observed between the $\mathrm{BB}$ $\mathrm{BB}_{(\mathrm{obR})}$ and $\mathrm{AA}_{(\mathrm{ob})} \mathrm{AA}_{(\mathrm{obR})}$ genotypes $(6.64$ vs $5.25 \mathrm{~cm} ; \mathrm{P}<0.01)$ (Table 9). A significant difference in body weight was detected between the $\mathrm{AB}_{(\mathrm{ob})} \mathrm{AA}_{(\mathrm{obR})}$ and $\mathrm{BB}_{(\mathrm{ob})} \mathrm{BB}_{(\mathrm{obR})}$ genotypes $(10.48$ vs $8.18 \mathrm{~kg} ; \mathrm{P}<0.05)$. Finally, abdominal circumference significantly differed between the $\mathrm{AA}_{(\mathrm{ob})} \mathrm{AA}_{(\mathrm{obR})}$ and $\mathrm{BB}_{(\mathrm{ob})} \mathrm{BB}_{(\mathrm{obr})}$ genotypes $(64.50$ vs $53.5 \mathrm{~cm} ; \mathrm{P}<0.01)$ (Table 10).

Table 9. Effect of combination genotype polymorphism on guard hair length.

\begin{tabular}{|c|c|c|}
\hline Genotype & Number & Guard hair length $\mathrm{P}<0.01$ \\
\hline 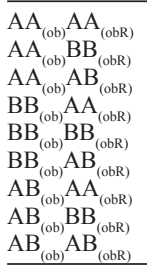 & $\begin{array}{r}2 \\
27 \\
21 \\
2 \\
17 \\
16 \\
5 \\
98 \\
76 \\
\end{array}$ & $\begin{array}{l}5.25^{\mathrm{C}} \\
6.07^{\mathrm{ABC}} \\
6.00^{\mathrm{ABC}} \\
6.25^{\mathrm{ABC}} \\
6.64^{\mathrm{A}} \\
5.87^{\mathrm{ABC}} \\
5.40^{\mathrm{BC}} \\
6.34^{\mathrm{AB}} \\
6.09^{\mathrm{ABC}}\end{array}$ \\
\hline
\end{tabular}

Values in same column capitals indicate $\mathrm{P}<0.01$.

Table 10. Effect of combination genotype polymorphism on body weight and abdominal circumference.

\begin{tabular}{|c|c|c|c|}
\hline Genotype & Number & Body weight $(\mathrm{P}<0.05)$ & Abdominal circumference $\mathrm{P}<0.01$ \\
\hline $\mathrm{AA}_{(\mathrm{ob})} \mathrm{AA}_{(\mathrm{obR})}$ & 2 & $10.82^{\mathrm{a}}$ & $64.50^{\mathrm{a}}$ \\
\hline $\mathrm{AA}_{(\mathrm{fb})} \mathrm{BB}_{(\mathrm{obR})}$ & 12 & $8.76^{\mathrm{ab}}$ & $55.25^{\text {bc }}$ \\
\hline $\mathrm{AA}_{(\mathrm{fb})}^{(\mathrm{ob})} \mathrm{AB}_{\text {(obR) }}$ & 13 & $9.26^{\mathrm{ab}}$ & $58.46^{\text {ab }}$ \\
\hline $\mathrm{BB}_{(\mathrm{fb})}^{(\mathrm{Bb})} \mathrm{BB}_{(\mathrm{obR} R)}$ & 6 & $8.18^{\mathrm{b}}$ & $53.5^{\mathrm{c}}$ \\
\hline $\mathrm{BB}_{(\mathrm{fb})} \mathrm{AB}_{(\mathrm{ob} R \mathrm{R})}$ & 8 & $9.42^{\mathrm{ab}}$ & $58.0^{\mathrm{abc}}$ \\
\hline $\mathrm{AB}_{(\mathrm{fb})} \mathrm{AA}_{(\mathrm{obR})}^{(\mathrm{obR})}$ & 6 & $10.84^{\mathrm{a}}$ & $61.83^{\mathrm{ab}}$ \\
\hline 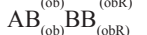 & 46 & $9.97^{\mathrm{ab}}$ & $59.93^{\text {ab }}$ \\
\hline $\mathrm{AB}_{(\mathrm{bb})} \mathrm{AB}_{(\mathrm{obk})}^{(\mathrm{obR})}$ & 49 & $10.64^{a}$ & $62.61^{\mathrm{a}}$ \\
\hline
\end{tabular}

Values in same column capitals indicate $\mathrm{P}<0.01$, while small letters indicate $\mathrm{P}<0.05$.

\section{DISCUSSION}

\section{Effect of the $\mathrm{OB}$ gene polymorphism on production performance of Arctic fox}

Leptin is a product of the OB gene and acts through its receptor OB-R. Leptin is primarily known for its role as a hypothalamic modulator of food intake, energy balance, fat stores, and body weight. Recent studies have shown that leptin may be involved in the development of respiratory diseases, such as pulmonary artery hypertension, chronic obstructive pulmonary disease, lung neoplasms, and asthma (Chai et al., 2013). The T alleles of both LEP g.1387C $>$ T and LEPR c.1987C $>$ T, which are fixed in Iberian pigs, lead to increased growth, fatness, and saturated fatty acid content in fat (Pérez-Montarelo et al., 2012). Sequence variation in the bovine leptin gene has been found to be associated with variation in carcass fat content and average daily gain as well as milk yield, milk somatic cell count, and several traits related to reproduction (Reicher et al., 2011). Another study scored the OB gene by PCRrestriction fragment length polymorphism and found that this gene had good genetic effects 
on Songliaohei pig meat quality and carcass traits ( $\mathrm{Li}$ et al., 2007). Correlation analysis of the leptin gene with growth traits in pigs showed that the C3469T SNP was significantly associated with average daily gain $(\mathrm{P}<0.01)$, such that individuals with the TT and $\mathrm{CC}$ genotypes had significantly higher average daily gain than individuals with TC. The C3952G SNP was suggested to be associated with live body length and longissimus dorsi muscle area $(\mathrm{P}<0.1)$ (Liu et al., 2008). These findings indicate the fact that the leptin hormone is involved in diverse biological processes, including regulation of food intake, body weight homeostasis, and energy balance. Mutations in the leptin gene are thus related to animal weight and fat content.

We evaluated the correlations between an SNP in the OB gene and growth traits in the Arctic fox. Foxes with the $\mathrm{AB}$ genotype presented significantly higher body weight and abdominal circumference than animals with the AA or BB genotypes $(\mathrm{P}<0.01)$. Similarly, foxes with the $\mathrm{AB}$ genotype had significantly longer fur $(\mathrm{P}<0.01)$ than those with the $\mathrm{AA}$ and $\mathrm{BB}$ genotypes. These results show that the combination of the $\mathrm{A}$ and $\mathrm{B}$ alleles is related to increased body weight, abdominal circumference, and fur length in the Arctic fox. Because the AB genotype showed the most favorable effects on body weight, abdominal circumference, and fur length, the detection of this allele combination may be used for marker-assisted selection.

\section{Effect of an OB-R gene polymorphism on production performance of Arctic fox}

LEPR is a key gene controlling food intake and energy homeostasis. A sequence variant of LEPR has been associated with growth, fatness, and body composition in several pig populations (Uemoto et al., 2012). This gene is thus considered to be a candidate gene for fatness traits. In a Duroc purebred population, the c.2002C $>$ T SNP of LEPR has a strong effect on backfat thickness, fat area ratios, and serum leptin concentration (Wang et al., 2011). The goose LEPR gene encodes a 1156-amino acid protein containing a signal peptide, a single transmembrane domain, and specific motifs involving putative leptin-binding and signal transduction. The deduced goose LEPR protein shows more than $90 \%$ identity with duck and $75 \%$ identity with chicken and turkey (Guo et al., 2008). Polymorphisms in the LEPR gene were shown to be associated with growth traits in the Nanyang breed. An SNP in the bovine LEPR gene had significant effects on body height, body length, body weight, heart girth, and average daily gain at 6 and 12 months of age $(\mathrm{P}<0.01$ or $\mathrm{P}<0.05)$. The LEPR gene is thus a strong candidate gene that affects growth traits in cattle (Li et al., 2003).

In this study, we analyzed the effects of a SNP in the 4th exon of the OB-R gene on the production performance in the Arctic fox. Foxes with the AB genotype had significantly higher carcass weight than those with the $\mathrm{BB}$ genotype $(\mathrm{P}<0.01)$, although guard hair length was greater in the latter group than in the $\mathrm{AA}$ and $\mathrm{AB}$ genotype groups $(\mathrm{P}<0.01)$. The $\mathrm{BB}$ genotype is the most advantageous for guard hair length and may be used for marker-assisted selection. However, the combinatorial AB genotype is the most effective for controlling carcass weight, and thus should be targeted in marker-assisted selection of carcass weight. The AA genotype slightly increased body weight, abdominal circumference, and fur length of the Arctic fox population and may be used as a reference for breeding.

\section{Effect of $\mathrm{OB}$ and $\mathrm{OB}-\mathrm{R}$ gene combinatorial genotypes on production performance of Arctic fox}

Animal growth and reproduction are complex traits controlled by multiple genes. 
Some of these genes function independently, whereas others have positive or negative interactions. In this study, we found that the interaction between the OB genotype and OB-R genotype affected the production performance of the Arctic fox. Foxes with the $\mathrm{AB}_{(\mathrm{ob})} \mathrm{AA}_{(\mathrm{obR})}$ genotype were the heaviest, with a body weight of $10.84 \mathrm{~kg}$. Foxes with this genotype were significantly heavier than those with the $\mathrm{BB}_{(\mathrm{ob})} \mathrm{BB}_{(\mathrm{obR})}$ genotype $(\mathrm{P}<0.05)$. The effect of the complex genotype on body weight was greater than the effect of any single genotype. The results revealed that $\mathrm{AB}_{(\mathrm{ob})} \mathrm{AA}_{(\mathrm{obR})}$ was a favorable genotype for body weight and may be targeted for marker-assisted selection.

Foxes with the $\mathrm{AA}_{(\mathrm{ob})} \mathrm{AA}_{(\mathrm{obR})}$ genotype had the longest abdominal circumference, $64.51 \mathrm{~cm}$, which was significantly greater than that for the $\mathrm{AA}_{(\mathrm{ob})} \mathrm{BB}_{(\mathrm{obR})}$ and $\mathrm{BB}_{(\mathrm{ob})} \mathrm{BB}_{(\mathrm{obR})}$ genotype groups $(\mathrm{P}<0.01)$. The effect of this complex genotype on abdominal circumference was

greater than the effect of any single genotype. The results revealed $\mathrm{AA}_{(\mathrm{ob})} \mathrm{AA}_{(\mathrm{obR})}$ as a favorable genotype for abdominal circumference, and this genotype can be used as a marker to accelerate breeding speed in the Arctic fox.

Foxes with the $\mathrm{BB}_{(\mathrm{ob})} \mathrm{BB}_{(\mathrm{obR})}$ genotype had the longest guard hair length $(6.64 \mathrm{~cm})$, which was significantly greater than the values for the $\mathrm{AA}_{(\mathrm{ob})} \mathrm{AA}_{(\mathrm{obR}) .}$ or $\mathrm{AB}_{(\mathrm{ob})} \mathrm{AA}_{(\mathrm{obR})}$ genotype groups $(\mathrm{P}<0.01)$. The effect of this complex genotype on guard hair length was greater than the effect of any single genotype. The results revealed $\mathrm{BB}_{(\mathrm{ob})} \mathrm{BB}_{(\mathrm{obR})}$ as a favorable genotype for guard hair length and may be used for marker-assisted selection.

From a functional perspective, leptin can act only in combination with OB-R; the $\mathrm{OB}$ gene cannot exert its function alone. Our correlation analysis of complex genotypes and production performance revealed an interaction between the OB and OB-R genes that has synergistic effects on the same traits. The use of favorable genotype combinations could enhance the breeding process of Arctic foxes.

\section{REFERENCES}

Chai SB, Wang J and Tang CS (2013). Research advances on leptin and respiratory diseases. Sheng Li Ke Xue Jin Zhan 44: 81-86.

Dai RJ, Li N and Wu CX (2000). Molecular cloning and analysing of porcine obese cDNA. Yi Chuan Xue Bao 27: 290297.

Guo Y, Chen H, Lan X, Zhang B, et al. (2008). Novel SNPs of the bovine LEPR gene and their association with growth traits. Biochem. Genet. 46: 828-834.

Li H, Deeb N, Zhou H, Mitchell AD, et al. (2003). Chicken quantitative trait loci for growth and body composition associated with transforming growth factor-beta genes. Poultry Sci. 82: 347-356.

Li Y, Zhang JB, Zhao ZH, Wu X, et al. (2007). Effects of Ob gene on meat quality and carcass traits in Songliaohei pig. Chin. J. Vet. Sci. 27: 919-921.

Liu D, Hu Y, Yang X, Liu Y, et al. (2011). Identification and genetic effects of a novel polymorphism in the distal promoter region of porcine leptin gene. Mol. Biol. Rep. 38: 2051-2057.

Liu DW, Du YJ and Zang H (2008). Identification of single nucleotide polymorphisms of the leptin gene and their effects on swine growth and carcass traits. Food Agric. Organ. U. N. 27: 89-96.

Ovilo C, Fernández A, Fernández AI, Folch JM, et al. (2010). Hypothalamic expression of porcine leptin receptor (LEPR), neuropeptide Y (NPY), and cocaine- and amphetamine-regulated transcript (CART) genes is influenced by LEPR genotype. Mamm. Genome 21: 583-591.

Pérez-Montarelo D, Fernández A, Folch JM, Pena RN, et al. (2012). Joint effects of porcine leptin and leptin receptor polymorphisms on productivity and quality traits. Anim. Genet. 43: 805-809.

Reicher S, Gertler A, Seroussi E, Shpilman M, et al. (2011). Biochemical and in significance of natural sequence variation in the ovine leptin gene. Gen. Comp. Endocrinol. 173: 636-667.

Tartaglia LA, Dembski M, Weng X, Deng N, et al. (1995). Identification and expression cloning of a leptin receptor, OBR. Cell 83: 1263-1271. 
Uemoto Y, Kikuchi T, Nakano H, Sato S, et al. (2012). Effects of porcine leptin receptor gene polymorphisms on backfat thickness, fat area ratios by image analysis, and serum leptin concentrations in a Duroc purebred population. Anim. Sci. J. 83: 375-385.

Wang F, Lu L, Yuan H, Tian Y, et al. (2011). Molecular cloning, expression, and regulation of goose leptin receptor gene in adipocytes. Mol. Cell. Biochem. 353: 267-274.

Zhang Y, Proenca R, Maffei M, Barone M, et al. (1994). Positional cloning of the mouse obese gene and its human homologue. Nature 372: 425-432. 